\title{
Sheep parasitism and its control by medicinal plants: A review
}

$\begin{array}{ll}\text { Review } & \text { Section of Parasitology, Department of Pathobiology, College of Veterinary and Animal } \\ \text { Article } & \text { Sciences, Narowal, Sub Campus UVAS, Lahore }{ }^{1} \text {, Department of Parasitology, University } \\ \text { of Agriculture, Faisalabad }{ }^{2} \text {, One health Laboratory, Centre for Advanced Studies in } \\ \text { Agriculture and Food Security, University of Agriculture, Faisalabad }{ }^{3} \text {, Department of } \\ \text { Pathobiology, Faculty of Veterinary and Animal Sciences University of Poonch Rawalakot, } \\ \text { Azad Kashmir }{ }^{4} \text {, Central Hi-Tech Laboratory, University of Agriculture, Faisalabad }{ }^{5} \text {, Animal } \\ \text { Sciences Institute, Livestock and Dairy Development Department, Quetta, Baluchistan }{ }^{6} \text {, } \\ \text { Pakistan }\end{array}$

\author{
Hafiz M Rizwan', Muhammad S Sajid ${ }^{2,3}$, Asim Shamim, Haider Abbas ${ }^{1}$, Abdul \\ Qudoos $^{5}$, Mahvish Maqbool ${ }^{2}$, Muhammad A Malik², Zubaria S Amin ${ }^{6}$
}

\begin{abstract}
Sheep production is a major source of income for resource poor farmers of the world. The main purpose of sheep raising is to fulfill the needs for mutton, milk, and wool production. Parasitic diseases, one of the principal hindrances in the development of commercial livestock business, are facilitated through favorable climatic conditions and lack of awareness. A variable prevalence ranging from 18.63 to $100 \%$ of different gastrointestinal parasite (GI) species in sheep were reported from different parts of the world. Incidence, prevalence, and intensity of parasitic infections is a multifactorial phenomenon and depends on environment, geographic location, pasture condition, host characteristics, grazing habits, and nutritional status. Prevalence of parasitic infections not only adversely affects animal health but also causes huge economic losses up to billions of rupees by decrease in milk, meat and wool production, retarded growth, parasite control measures and death of animals. For the control of GI parasites in small ruminants especially kept by resource-poor farmers, it is better to identify the burden and types of helminths along with specific risk factors associated with helminthosis of a specific area. Factors responsible for development of resistance are lavish use of anti-parasitic drugs, poor efficacy of anti-parasitic agents, inadequate dose level, low protein diet and environmental toxicity. Due to limitations of chemotherapy during the past decade, use of plants with anthelmintic properties (ethnoveterinary medicine) are under consideration around the world. A number of plant species have been identified with anti-parasitic properties that may disturb the regular physiological functions of parasites. Use of plants with anthelmintic properties is considered the best choice for control of parasites in the present scenario. In this review, sheep production, GI parasitic infection of sheep, medicinal plants, and their uses for control have been described.
\end{abstract}

Keywords: gastrointestinal parasites, phytotherapy, prevalence, sheep, treatment.

Received: 1 April, 2021, Accepted: 16 Jnue, 2021.

Corresponding Author: Hafiz M. Rizwan, Tel.: +92 3367044471, E-mail: hm.rizwan@uvas.edu.pk

Asim Shamim, Tel.: +92 5824960000, E-mail: asimshamim@upr.edu.pk

Print ISSN: 1687-7942, Online ISSN: 2090-2646, Vol. 14, No. 2, August, 2021.

\section{INTRODUCTION}

The economy of a country depends upon definite factors, and livestock is one of them. Livestock are the main source of wool, milk, meat, manure, and hides ${ }^{[1]}$. In the world, about 770.8 million tons of milk and 65,838 thousand tons of meat are produced from large ruminants; 4.5 million tons of milk and 15048 tons of meat from small ruminants ${ }^{[2,3]}$. The livestock sector plays a vital role in agriculture economy of Pakistan and shares more than $50 \%$ in gross domestic product (GDP). Main products obtained from sheep industry are milk, mutton and wool. In the sheep production system, wool is a good source of earning. However, milk obtained from sheep industry cannot meet the milk requirements, although it is especially good in quality and suitable for human consumption ${ }^{[4]}$. On the otherhand, parasitic infection is one of the most prevailing reasons that prevents achievement of all these benefits from sheep production system. Due to poor housing system, malnutrition, poor production system, management practices and burden of parasitic diseases small ruminant industry is not getting full benefits $^{[5,6]}$.

For the control of GI parasites in small ruminants especially reared by resource-poor farmers, it is better to identify the burden and types of helminths along with specific risk factors associated with helminthosis of specific area ${ }^{[7]}$. Breakdown of life cycle of GI parasites is the main goal in attempting the 
control of parasitic infection. Use of anthelminthics and proper management (of both animals and pastures) help to disturb the life cycle of GI parasites. Specific combination of these factors usually gives the best results for control of GI parasites ${ }^{[8]}$. In developing countries, anti-parasitic drugs are used lavishly for the control of parasitic infections especially by smallholder farmers, leading to the development of resistance. Other factors responsible for development of resistance are: poor efficacy of anti-parasitic agents, inadequate dose level, low protein diet and environmental toxicity ${ }^{[9]}$. Development of resistance against anthelminthics and their residual effects stimulate scientists to investigate alternative sources to control parasitic infection and to improve public health ${ }^{[10]}$. Keeping in view the limitations of chemotherapy, alternative solutions like biological control of parasites, use of vaccines and development of resistant host genotypes are being considered.

During the past decade, use of plants with anthelmintic properties (ethnoveterinary medicine) is also under consideration around the world ${ }^{[11-15]}$. A number of plant species with anti-parasitic properties were identified. Fundamental mechanisms involved in inducing these effects were not completely investigated but they may consist of direct, indirect, or combined effects $^{[16]}$. In direct effects, components of plants disturb the regular physiological functions as reproduction, food absorption and mobility of GI parasites by directly interacting with their surface proteins ${ }^{[17]}$. In indirect effects, condensed tannins (CT) released by plants build complexes with proteins and are passed to the abomasum without ruminal degradation. In the abomasum dissociation of these complexes releases proteins that are ready for absorption ${ }^{[18]}$.

In this review, the importance of sheep production in the economy of world, prevalence and species of GI parasites, strategies to control GI parasites, medicinal plants, and their uses for the control of GI parasites are described.

\section{Sheep production}

Nowadays, the livestock sector is one of the most secure and reliable sources of income for smallholder farmers around the world ${ }^{[19]}$. Small ruminant farming in comparison with large animals is less expensive due to low maintenance cost, expenditures, startup investment and feedstuffs requirments ${ }^{[20]}$. Different Asian countries are providing hygienic food and contribute to their economy by sustaining the small ruminant production system ${ }^{[21]}$. In Pakistan, livestock share in agriculture has increased from 55.5- 59.5\%, and the role in GDP has also increased form 11.5-11.9\%. Similarly, a 2.7 billion increase in increment is reported in gross value due to livestock involvement ${ }^{[22]}$. In Pakistan, the four practiced production systems include household, nomadic, sedentary, and transhumant.
In nomadic and transhumant systems, 90\% feed is provided by rangelands ${ }^{[23]}$.

Among sheep producing countries, Pakistan is the $11^{\text {th }}$ in number. A total of 26488 sheep are present in Pakistan and among these, 6362 (24\%) are raised in Punjab. Baluchistan shares with $42 \%$ in total sheep population while $16 \%$ are from Sindh and $18 \%$ from Khyber Pakhtown Khawah ${ }^{[24]}$. In Pakistan, about 28 recorded sheep breeds are divided into thin tail and thick tail categories. Environmental conditions of Pakistan are favorable for parasites propapagation and survival in pastures round the year ${ }^{[6]}$. Those areas where parasite prevalence is not high as in Sweden, Denmark, Netherlands and United Kingdom, production losses are relatively low ${ }^{[25]}$.

\section{Gastrointestinal parasites}

Livestock play a vital role in agriculture economy, but due to poor management practices chances for parasitic infections increase ${ }^{[26]}$. Grazing is the most common feeding method used for sheep; so, there are chances of higher worm load. Pastures are considered the most suitable locale for transmission of parasites, as most parasites hibernate in pastures and complete their lifecycle by gaining entry in the animal body. Parasites can inversely affect livestock and cause damage by reducing wool and hair growth, as well as cause blood loss and reduced body growth. Among parasitic infections that cause huge economic losses to the livestock industry, are those due to endoparasites (roundworms, tapeworms, flukes and coccidia), which are the most severe ${ }^{[27]}$. Among endoparasites, Heamoncus $(H$.$) contortus is the biggest threat to the$ livestock and sucks blood (approximately $0.05 \mathrm{ml}$ blood per worm per day) from abomasum directly ${ }^{[28]}$. Others that are gaining more importance e.g., Trichostrongylus Cooperia, Nematodirus and Ostertagia species should be considered while treating parasitic infections. Different studies have shown that losses caused by these parasites are more severe as compared to other infections ${ }^{[29]}$.

Prevalence of parasites depends on a variety of factors as environment, volume and height of pasture, geographical location, grazing habits, nutritional status of hostand immunological factors. Along with breed, age, and epidemiological data (of both husbandry practices and physiological factors), involvement of parasitic species are important factors affecting the prevalence of parasites ${ }^{[30]}$. In small ruminants, parasitic infections cause decrease in resistance against diseases, improper feed utilization and decrease in weight gain ${ }^{[31]}$.

For better control of parasitic infections, environmental factors and proliferating velocity of parasites should be taken into consideration. Although drugs used against parasites are of great value, but the increasing resistance to these drugs (because of their broad spectrum and excessive use), cost of drugs 
and their remnants in blood and meat are the leading causes to find an alternative source to overcome these problems $^{[32,33]}$.

Gastrointestinal parasites directly affect the host by disturbing metabolism, feeding on blood and causing damage to the intestinal wall ${ }^{[34]}$. These parasites are also responsible for low food conversion ratio, low food absorption by intestinal wall and decreased appetite ${ }^{[35]}$. Parasitic infection may lead to production losses as decrease in growth rate and reproduction ${ }^{[36]}$ as well as resulting in compromising the immune status of host and in turn increasing animal susceptibility for harmful pathogens ${ }^{[37]}$.

\section{Prevalence of gastrointestinal parasites}

Frequency of parasitic infections in sheep depends upon factors that include host breed, parasite species, epidemiological data, host age, humidity, parasite developmental stages, rainfall, temperature managemental practices and geography ${ }^{[38]}$. Previous data indicates that GI helminths in sheep ranged from 25.1-92\% in Pakistan ${ }^{[15,37,39-43]}$.

A wide range of parasites is prevalent in the sheep population of Pakistan such as Avitellina (Av.) centripunctata, Paramphistomum (P.) explanatunz, P. cervi, Cotylophoron (Co.) cotylophorum, Ostertagia (Os.) Circumcincta, Os. ostertagi, Moniezia (Mo.) expansa, Mo. betzedetzi, Bunostomum (B.) trigonocephalum, Chabertia (Ch.) ovina, Trichuris (Tr.) ovis, and Haemonchus (H.) contortus ${ }^{[44]}$; as well as Trichostrongylus sp., Tr. globulosa, Os. circumcinta, Strongyloides (S.) papillosus, Mo. Expansa, Fasciola (F.) hepatica, Co. cotylophorum ${ }^{[45]}$. Studies from other countries revealed other species like Dicrocoelium (D.) dendriticum, Strongyle sp., F. hepatica, Nematodirus sp., and Trichuris sp., (Greece) ${ }^{[46]}$; Strongyloides sp., Schistosoma (Sc.) indicum, Trichris sp., Bunostomum sp., F. gigantica and Strongyles sp., (Bangladesh) ${ }^{[47]}$; and Bunostomum sp., Haemonchus sp., Trichostrongylus sp., Strongyloides sp., and Oesophagostomum sp., (Ethiopia) ${ }^{[48]}$. According to Domke et al. ${ }^{[49]}$, important helminths species infecting sheep in Norway are Nematodirus (N.) filicollis, N. battus, N. spathiger, Cooperia (C.) oncophora, H. contortus, Os. trifurcate, Os. circumcincta, Ch. ovina, Trichostrongylus (T.) vitrinas, $T$. colubriformis, T. capricola, B. trigonocephalum, Tr. ovis. Oesophagostomum (O.) venulosum. In another study, the parasitic species found in sheep from Ghana were Gaigeria pachyscelis, Cooperia sp., Trichostrongylus sp., Strongyloides (S.) papillosus, $H$. contortus, and $O$. columbianum ${ }^{[50]}$. Variable prevalences and species of GI parasites reported from different localities of Pakistan and other parts of the world are outlined in tables 1 and 2 , respectively.

\section{Strategies to control gastrointestinal parasites}

For the control of GI parasites in small ruminants, especially those kept by smallholder farmers, it is better to identify burden and types of helminths along with specific risk factors associated with helminthiasis in the specific area ${ }^{[6,7]}$. The breakdown of GI parasites' life cycles through anthelmintics and proper managemental practices are the best methods to control parasitic infections ${ }^{[51]}$. However the development of drug resistance to almost all parasitic helminths classes due to regular use of anthelmintics over past decades became a problem all around the globe.

Most of the anthelminthic compounds are used without registration and proper tests which directly affects their efficacy ${ }^{[8]}$. Inadequate use of anthelminthic compounds, and poor efficacy of anti-parasitic agents, low protein diet and environmental toxicity are the factors that result in resistance development ${ }^{[9]}$. Anthelminthic treatment of small ruminants in most countries is not being practiced regularly in a systemic way, which may have a considerable effect on the prevalence and abundance of parasitic species. Furthermore, sample size and nature of sample sources (faecal or autopsies) are also considerable factors in this regard ${ }^{[52-54]}$. Keeping in mind the importance of parasitic infection and development of drug resistance, control trials for checking the efficacy of anthelmintic compounds should be carried out.

The development of resistance to anthelmintics and presence of drug residues in the food chain stimulate the investigation of alternative sources to control parasitic infection and improve public health. Anti-parasitic agents extracted from plants have also been used in human and animal populations but as compared to commercial anthehelmintics, their scientific evaluation is limited ${ }^{[55]}$.

\section{Alternate approaches to control parasites}

Anthelmentic resistance is widespread in parasitic helminths, especially in nematode population around the world ${ }^{[56]}$. To overcome this problem, an alternate strategy to control resistance is the manipulation of genetic variation. There are three ways to introduce the genetic variation i.e., by selection of particular breeds, cross-breeding and selection among breeds ${ }^{[57]}$. In Pakistan, some sheep breeds are resistant to $H$. contortus e.g., the native Lohi breed ${ }^{[58]}$. These methods are sustainable, efficient, safe, and economical; but the only hindrance is the need of expertise in genetic field ${ }^{[59]}$. Another option is the grazing management and its strategies e.g., rotational grazing, and movement to clean pastures ${ }^{[59]}$. Grazing management scheme is related to ecology of helminth larvae, plant species in grazing pasture, epidemiology of GI parasites, climatological status, schedule of using anthelmintics and prevailing local conditions ${ }^{[60,61]}$. Another method of control is by biological monitoring of a nematophagous fungus (Duddingtonia flagrans) which directly decreases the number of infective L3 larvae in pastures ${ }^{[62]}$. Fungal spore addition in diet is also a method for control of worms ${ }^{[63]}$. 


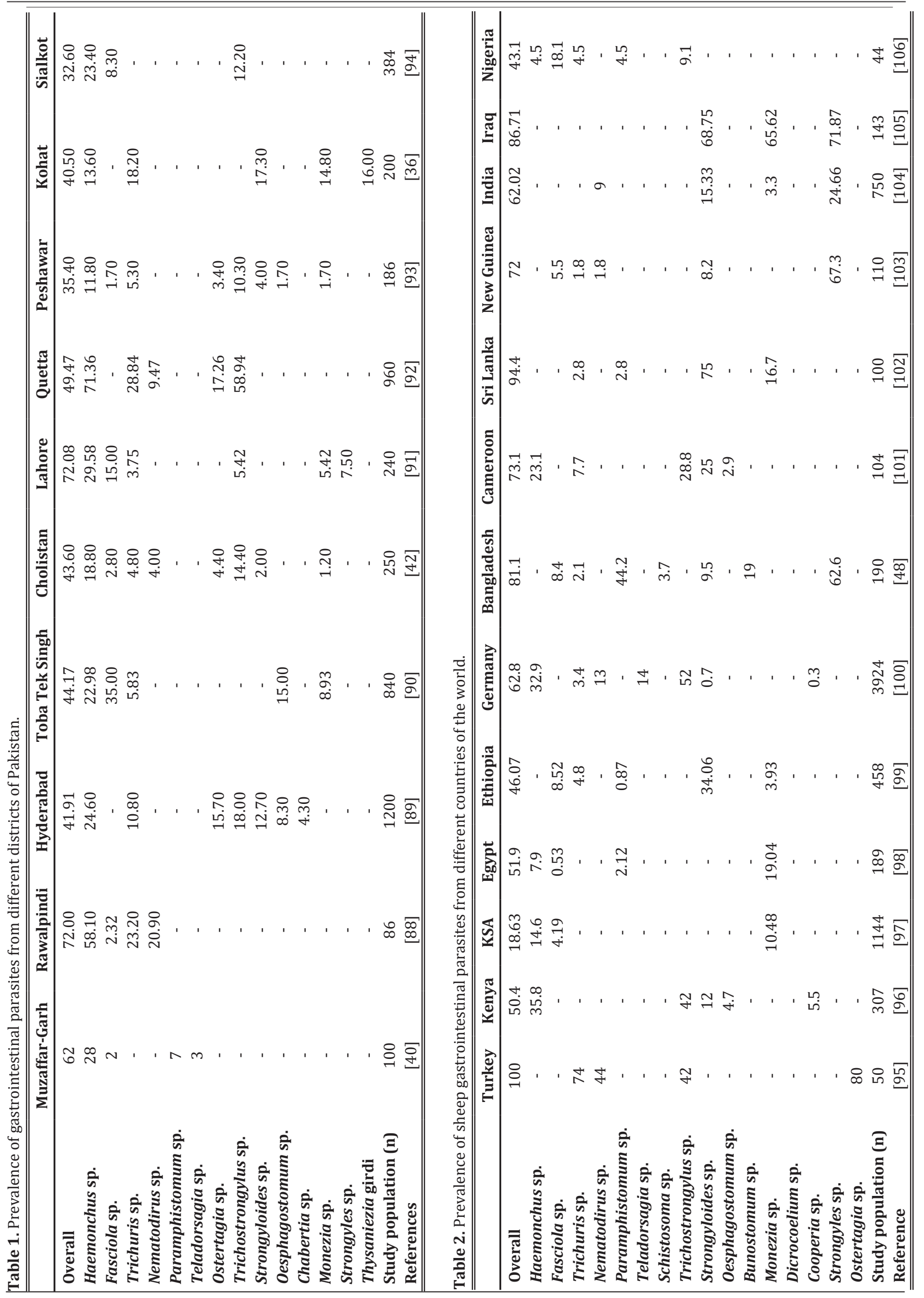


The use of a botanical dewormer is a good approach and a possible solution to combat anthelmintic resistance ${ }^{[64]}$. Plants have been used from ancient times for treatment purposes of domesticated animals and humans, constituting a large source of antibacterials, antiparasitics and insecticides agents ${ }^{[65]}$. Plants are being studied in different parts of the world for their ovicidal, adulticidal and larvicidal activity ${ }^{[11,12,14,52,55,66-68]}$.

\section{Phytotherapy}

A traditional medicinal application that uses extracts from botanical origin to treat the animal and human illness is referred to as phytotherapy ${ }^{[60,70]}$. Phytomedicine, botanical medicine and herbal medicine are the other names for phytotherapy ${ }^{[71]}$. Herbal medicine has been considered a part of ethnoveterinary knowledge (EVK) or ethnoveterinary medicine (EVM). Definition of EVM is the interdisciplinary acquisition of local knowledge and its related expertise concerning the care of livestock products; with the primary objective of flourishing animal resources leading indirectly to improved human revenue $^{[13]}$. There are three main purposes of systematic research in EVM: firstly it can give necessary knowledge for maintaining therapeutic practices in livestock that can be satisfied according to local environmental conditions; secondly it can contribute to new curative drugs in the pharmacopoeia; and lastly it has a role in conservation of biodiversity ${ }^{[72]}$.

About 122 chemical components derived from the medicinal plants, were identified by researchers in the field of herbal medicine in $2001^{[73]}$. Plants have the capability to develop certain chemicals which can provide protection against predators including herbivorous mammals, insects, and fungi ${ }^{[69]}$. These chemical components are dangerous to their predators, but they have been found beneficial in treating animals' and humans' ailments. About 12000 secondary metabolites of botanical origin have been isolated and these numbers are $10 \%$ less than the entire chemical compounds. Chemical components of plants have an effect on animal and human bodies due to presence of available receptor molecules ${ }^{[74]}$. However, inappropriate formulations and drug interactions of plants like Dryopteris (Male Fern), Viscum (Mistletoe) and Corynanthe (Yohimbe) can result in life threatening reactions ${ }^{[75-77]}$.

\section{Control of parasites through plant sources}

The alternative sources for anthelminthic drugs are of great interest to the animal rearer because of their herbal nature and easy availability ${ }^{[78]}$. For consumers of both agriculture and livestock it is important that meat and other livestock products should be clean and green. In the clean sense it should be free from drugs residues treatments of animals such as antibiotics and anthelmintics, which may have serious impact on human health. Green sense, applies to the production of livestock using green feeding system in which animals are reared in controlled houses rather than the In vitro feeding system $^{[79]}$. In Europe, most countries are working to establish organic farming by grazing animals outside on patures, and without the use of any chemical substances such as antibiotics or anthelmintics. Parasitic infection that may be acquired by grazing, should be treated using specific herbal therapy rather than chemical treatment. At first, alternative herbal anthelmintics (areca nut, castor oil, clove, and extracts of garlic) were applied to control parasites, but after the discovery of synthetic drugs, their use was reduced ${ }^{[80]}$.

In Asia and other regions, many medicinal plants are being used as anthelmintics but due to lack of knowledge about these plants, their effectiveness is not satisfactory. Furthermore, they are used excessively due to their easy availability ${ }^{[81,82]}$. The worm infestation in sheep was reported to decrease up to $50 \%$ after the use of medicinal plants like Lotus pedunculatus and Hedysarum corinarum. Certain scientific work on tannin effectiveness against worms has shown that it is beneficial in either passive or active ways ${ }^{[83]}$. In the latter tannin binds with the external and internal proteins of parasites and changes their parasitic activity. Contrarily, in the passive manner condensed tannin binds with the ruminal proteins and reaches the intestine for maximum absorption and increases the immunity. Both possible actions of CT have no effect on the different ages of lambs, and after oral administartion, they showed good anthelmintic results and reduced the faecal egg count (FEC) ${ }^{[84]}$. Similarly, CT extracted from seven herbages were given to lambs and there was a relation between the amount of tannin and $3^{\text {rd }}$ larval stage of Trichostrongylus colubriformis indicating that increased tannins decrease the amount of larvae in the animal body ${ }^{[83]}$. Similarly, pineapple friuts (Ananas comosus) have many medicinal properties in wound healing, in cancer treatment, and increases drug metabolism so that it becomes more beneficial ${ }^{[85]}$. Bromelain is a compound obtained from pineapple trees, particularly the stem. It acts on the cuticle of parasites and being proteinase in nature, it removes the cuticles and finally kills them by damaging their outer covering ${ }^{[6]}$. Similarly, there are also other plants that have characteristic anthelmintic activities such as Azadirachta indica of the family Mileaceae, which can be used against Heamonchus infection of ruminants $^{[87]}$. A list of medicinal plants used to control GI parasites is given in table (3).

Conclusion: Sheep rearing at small and large levels play an important role in the economy of farmers and overall, in the economy of country. Parasitic infection is one of the major hindrances not only to the development of encomy but also in increasing the cost of production. Cost of chemicals to control GI parasites, development of resistance against these chemicals and presence of residues of these chemicals in livestock are major problems facing the sheep industry. To overcome these problems, identification of active ingredients in local medicinal plants according to geographic locations, and determination of their mode of action is crucial. 
Sheep parasitism and control

Rizwan et al.,

Table 3. List of medicinal plants used to control GI parasites of sheep.

\begin{tabular}{|c|c|c|c|c|}
\hline Scientific name & Local name & Plant source & Preparation method & Reference \\
\hline Agapanthus praecox & African Lily & Leaves & Infusion & [107] \\
\hline Centella coriacea & Swamp Pennywort & Bark & Decoction & [107] \\
\hline Cussonia spicata & Natal cabbage Tree & Bark & Infusion & {$[107]$} \\
\hline Gasteria bicolor & Elephant's Foot & Leaves & Infusion & [107] \\
\hline Bulbine latifolia & Broad leaved bulbine & Leaves & Decoction & {$[107]$} \\
\hline Bulbine frutescens & Cat's tail & Whole plant & Infusion & [107] \\
\hline Bulbine abyssinica & Snake flower & Leaves & Decoction & [107] \\
\hline Capparis sepiaria & Caperbush & Roots & Infusion & [107] \\
\hline Gunnera perpensa & River pumpkin & Tuber & Decoction & [107] \\
\hline Hypoxis argentea & Yellow stars & Tuber & Decoction & [107] \\
\hline Ocotea bullata & Black stinkwood & Bark & Decoction & [107] \\
\hline Pittosporum viridiflorum & Cheese wood & Bark & Infusion & [107] \\
\hline Rumex lanceolatus & Common dock & Roots & Decoction & [107] \\
\hline Ptaeroxylon obliquum & Sneezewood & Leaves & Decoction & [107] \\
\hline Ziziphus mucronata & Buffalo Thorn & Leaves & Infusion & [107] \\
\hline Hermannia incana & Sweet yellow bells & Whole plant & Decoction & [107] \\
\hline Grewia occidentalis & Crossberry & Bark & Decoction & {$[107]$} \\
\hline Leonotis leonurus & Wild dagga & Leaves & Decoction & [108] \\
\hline Aloe ferox & Bitter aloe & Leaves & Decoction & [109] \\
\hline Harpephyllum caffrum & Wild plum & Bark & Decoction & [110] \\
\hline Acokanthera oppositifolia & Bushman's poison & Leaves & Decoction & [110] \\
\hline Aloe arborescens & Bitter aloe & Leaves & Decoction & [110] \\
\hline Elephantorrhiza elephantina & Elephant's root & Roots & Decoction & [110] \\
\hline Schotia latifolia & Bush Boerbean & Bark & Decoction & [110] \\
\hline Pelargonium reniforme & Pelagonium & Tuber & Decoction & [110] \\
\hline Zanthoxylum capense & Small knobwood & Roots & Decoction & [110] \\
\hline Teucrium trifidum & Dutchmen's fever plant & Leaves & Infusion & [111] \\
\hline Strychnos henningsii & Red bitter berry & Bark & Decoction & [112] \\
\hline Albuca setosa & Ingwebeba & Tuber & Decoction & [113] \\
\hline Mallotus philippensis & Kamala & Fruits & Decoction & [69] \\
\hline Azadirachta indica & Neem & Leaves & Decoction & [60] \\
\hline Calotropis procera & Aak & Flowers & Decoction & [69] \\
\hline Cucurbita maxima & Kadu & Seeds & Decoction & [69] \\
\hline Papaver somniferum & Post & Seeds & Decoction & [69] \\
\hline Withania coagulans & Paneer & Aerial parts & Decoction & [69] \\
\hline Ferula assa-foetida & Heang & Latex & Decoction & [69] \\
\hline Nicotiana tabacum & Tambaco & Leaves & Decoction & [69] \\
\hline Punica granatum & Anar Fruit & Fruit Peel & Decoction & [69] \\
\hline Trachyspermum ammi & Ajjwain porji & Seeds & Decoction & [69] \\
\hline
\end{tabular}

Authors' contribution: All authors made substantial contributions to the manuscript; revised it critically for important intellectual content and language editing; and gave final approval of the version to be published. Declarations of interest: No potential conflicts of interest.

Financial support: Nil.

\section{REFERENCES}

1. Wasim MP. Trends and growth in livestock population in Sindh: A comparison of different censuses. Indus J Manag Social Sci 2007; 1:58-75.

2. FAO. Rural income generating activities database, 2009. (Available at www.fao.org/es/ESA/riga/ english/index_en.htm).

3. Malik MA, Sajid MS. Medicinal plants as an alternative to combat gastrointestinal parasitism. Technology times 2015; 45:1-4.

4. Ilişiu E, Dărăban S, Radu R, Pădeanu I, Ilişiu VC, Pascal $\mathrm{C}$, et al. The Romanian Tsigai sheep breed, their potential, and the challenges for research. Appl Agric Forestry Res 2013; 2:161-170.
5. Kumar N, Rao TKS, Varghese A, Rathor VS. Internal parasite management in grazing livestock. J Parasite Dis 2013; 37:151-157.

6. Ahmad M, Khan MN, Sajid MS, Muhammad G, Qudoos A, Rizwan HM. Prevalence, economic analysis and chemotherapeutic control of small ruminant fasciolosis in the Sargodha district of Punjab, Pakistan. Vit Ital 2017; 53:4753.

7. Ayana T, Ifa W. Major gastrointestinal helminth parasites of grazing small ruminants in and around Ambo town of Central Oromia, Ethiopia. J Vet Med Anim Health 2015; 7:64-70.

8. Atnafe F, Melaku A. Bovine fasciolosis in Ginnir district: Prevalence and susceptibility to commonly used anthelmintics. J Vet Adv 2012; 2:539-543

9. Smith MC, Sherman DM. 2nd Ed. 2009. Goat Medicine. Wiley-Blackwell. ISBN 978-0-7817-9643-9.

10. Qadir S, Dixit KA, Dixit P. Use of medicinal plants to control Haemonchus contortus infection in small ruminants. Vet World 2010; 3:515-518.

11. Peixoto MG, Costa-Júnior LM, Blank AF, Lima AS, Menezes TSA, Santos DA et al. Acaricidal activity of essential oils from Lippia alba genotypes and its major components carvone, limonene, and citral 
against Rhipicephalus microplus. Vet Parasitol 2015; 210:118-122.

12. Tugume $\mathrm{P}$, Kakudidi E, Buyinza M, Namaalwa J, Kamatenesi M, Mucunguzi P, et al. Ethnobotanical survey of medicinal plant species used by communities around Mabira Central Forest Reserve, Uganda. J Ethnobiol Ethnomed 2016; 12:5.

13. Wajiha, Qureshi NA. In vitro anticoccidial, antioxidant activities and biochemical bcreening of methanolic and aqueous leaves extracts of selected plants. Pak Vet J 2021; 41(1):57-63

14. Kebede A, Ayalew S, Mesfin A, Mulualem G. An ethnoveterinary study of medicinal plants used for the management of livestock ailments in selected Kebeles of Dire Dawa Administration, eastern Ethiopia. J Plant Sci 2017; 5: 34-42.

15. Rizwan HM, Sajid MS, Iqbal Z, Saqib M. Association of phytomineral with gastrointestinal parasites of grazing sheep in Sialkot district, Punjab, Pakistan. Pak J Agricul Sci 2019; 56(2):459-468.

16. Athanasiadou S, Kyriazakis I, Jackson F, Coop RL. Effects of short-term exposure to condensed tannins on adult Trichostrongylus colubriformis. Vet Rec 2000; 146:728-732.

17. Heckendorn F. Kondonsierte tannine eine möglichkeit zur Kontrolle von Magen-Darm-Würmern? Forum 2005; 1/2:11-13.

18. Min BR., Miller D, Hart SP, Tomita G, Loetz E, Sahlu T. Direct effects of condensed tannins on gastrointestinal nematodes in grazing Angora goats. J Anim Sci 2003; 81:23.

19. Herrero M, Thornton PK, Notenbaert AM, Wood S, Msangi S, Freeman HA et al. Smart investments in sustainable food production: Revisiting mixed croplivestock systems. Sci 2010; 327:822-825.

20. Adesehinwa AOK, Okunola JO, Adewumi MK. Socioeconomic characteristics of ruminant livestock farmers and their production constraints in some parts of south-western Nigeria. Livest Res Rural Devel 2004; 16:82-93.

21. Ronchi B, Nardone A. Contribution of organic farming to increase sustainability of Mediterranean small ruminants' livestock systems. Livest Prod Sci 2003; 80:17-31.

22. Anonymous. Population Census Organization. District Census Reports. Statistics Division, Ministry of Economic Affairs and Statistics, Government of Pakistan, Islamabad, Pakistan. 2014.

23. Khan MF, Anderson DM, Nutkani MI, Butt NM. Preliminary results from reseeding degraded Dara Ghazi Khan Rangeland to improve small ruminant production. Small Rum Res 1999; 32:43-49.

24. Sarwar M, Shahzad MA, Nisa M. Small ruminant production in Pakistan. Egptian J Sheep Goat Sci 2010; 5:17-26.

25. Jackson F, Coop RL. The development of anthelmintic resistance in sheep nematodes. Parasitol 2000; 120:95-107.

26. Sultan K, Elmonir W, Hegazy Y. Gastrointestinal parasites of sheep in Kafr Elsheikh governorate, Egypt:
Prevalence, control and public health implications. Beni-Suef Uni J Basic Appl Sci 2016; 5:79-84.

27. Acharya KP, Nirmal BK, Kaphle K, Mahato MK, Yadav GP, Ranae HB. Prevalence of gastrointestinal and liver parasites in yaks in the cold desert area of lower Mustang, Nepal. Asian Pacific J Trop Dis 2016; 6:147150.

28. Tak IUR, Chishti MZ, Ahmad F. Epidemiological studies of abomasal nematodes of sheep of Kashmir Valley with particular reference to Haemonchus contortus. Nature Sci 2013; 11:34-39.

29. Qudoos A, Khan MN, Sajid MS, Muhammad G. Correlation of trace mineral profiles with gastrointestinal worm burden in rangeland sheep of Chakwal District, Punjab, Pakistan. Int J Agric Biol 2017; 19:140-144.

30. Tembely S, Lahlou-Kassi A, Rege JE, Sovani S, Diedhiou ML, Bake RL. The epidemiology of nematode infections in sheep in a cool tropical environment. J Vet Parasitol 1997; 70:129-141.

31. Pedreira J, Paz-Silva A, Sanchez-Andrade R, Suarez JL, Arias M, Lomba C et al. Prevalences of gastrointestinal parasites in sheep and parasite control practices in NW Spain. Prev Vet Med 2006; 75:56-62.

32. Whelan M, Kinsella B, Furey A, Moloney M, Cantwell H, Lehotay SJ, et al. Determination of anthelmintic drug residues in milk using ultra high performance liquid chromatography-tandem mass spectrometry with rapid polarity switching. J Chromat A 2010; 1217:4612-4622.

33. Cooper KM, Whelan M, Kennedy DG, Trigueros G, Cannavan A, Boon PE, et al. Anthelmintic drug residues in beef: UPLC-MS/MS method validation, European retail beef survey, and associated exposure and risk assessments. Food Additives \& Contaminants: Part A 2012; 5:746-760.

34. Hughes J, Albon SD, Irvine RJ, Woodin S. Is there a cost of parasites to caribou? Parasitol 2009; 136:253-265.

35. Foreyt WJ. Veterinary Parasitology Reference Manual. Ames, 2001. IA: Iowa State University Press, USA.

36. Stien A, Irvine RJ, Langvatn R, Ropstad E, Halvorsen O, Albon SD. The impact of gastrointestinal nematodes on wild reindeer: experimental and cross-sectional studies. J Anim Ecol 2002; 71:937-945.

37. Rashid A, Khattak MNK, Khan MF, Ayaz S, Rehman AU. Gastrointestinal helminthoses: Prevalence and associated risk factors in small ruminants of district Kohat, Khyber Pakhtunkhwa, Pakistan. J Anim Plant Sci 2016; 26(4):956-962.

38. Nwosu CO, Madu PP, Richards WS. Prevalence and seasonal changes in the population of gastrointestinal nematodes of small ruminants in the semi-arid zone of north-eastern Nigeria. Vet Parasitol 2007; 144:118124.

39. Raza MA, Iqbal Z, Jabbar A, Yaseen M. Point prevalence of gastrointestinal helminthiasis in ruminants in southern Punjab. Pakistan. J Helminthol 2007; 81:323-328

40. Gadahi JA, Arshad MJ, Ali Q, Javaid SB, Shah SI. Prevalence of gastrointestinal parasites of sheep 
and goats in and around Rawalpindi, Islamabad. Vet World 2009; 2:51-53.

41. Farooq Z, Mushtaq S, Iqbal Z, Akhtar S. Parasitic helminths of domesticated and wild ruminants in Cholistan desert of Pakistan. Int J Agric Biol 2012; 14:63-68.

42. Raza MA, Younas M, Schlecht E. Prevalence of gastrointestinal helminths in pastoral sheep and goat flocks in the Cholistan desert of Pakistan. J Anim Plant Sci 2014; 24:127-134.

43. Sohail M, Nauman-ul-Islam M, Shah SSA, Shah IA, Raziq A, Ilyas M. Incidence of gastrointestinal parasites in beetal goats at district Peshawar, Pakistan. Adv Anim Vet Sci 2017; 5:205-207.

44. Khan MN. A survey of gastrointestinal helminthiasis and study of taxonomy of the species of genus Ostertagia in sheep and goats. M.Sc Thesis. 1985. Department of Veterinary Parasitology, University of Agriculture, Faisalabad, Pakistan.

45. Ijaz M, Khan MS, Avais M, Ashraf K, Ali MM, Khan MZU. Infection rate and chemotherapy of various helminthes in diarrhoeic sheep in and around Lahore. J Anim Plant Sci 2009; 19:13-16.

46. Kantzoura V, Kouam MK, Theodoropoulou H, Feidas $\mathrm{H}$, Theodoropoulos G. Prevalence and risk factors of gastrointestinal parasitic infections in small ruminants in the Greek temperate mediterranean environment. Open J Vet Med 2012; 2:25-33.

47. Sangma A, Begum N, Roy BC, Gani MO. Prevalence of helminth parasites in sheep (Ovis aries) in Tangail district, Bangladesh. J Bangladesh Agri Univ 2012; 10:235-244.

48. Zeryehun T. Helminthosis of sheep and goats in and around Haramaya, southeastern Ethiopia. J Vet Med Anim Health 2012; 4:48-55.

49. Domke AVM, Chartierb C, Gjerdec B, Leined N, Vatne $\mathrm{S}$, Stuen S. Prevalence of gastrointestinal helminths, lungworms and liver fluke in sheep and goats in Norway. Vet Parasitol 2013; 194:40-48.

50. González-Garduño R, Gives PM, Torres-Hernández G. Variability in the fecal egg count and the parasitic burden of hair sheep after grazing in nematode infected paddocks. Pesq Vet Bras 2013; 33:469-475.

51. Rahmann G, Seip H. Alternative strategies to prevent and control endoparasite diseases in organic sheep and goatfarming systems: a review of currentscientific knowledge". In: Rahmann G (ed.). Ressortforschung für den Ökologischen Landbau 2006; 298:49-90.

52. Githiori JB, Hogland J, Waller PJ, Baker RL. Evaluation of anthelmintic properties of some plants used as livestock dewormers against Haemonchus contortus infection in sheep. Parasitol 2004; 129:245-253.

53. Muhammad $A$, Ahmed $H$, Iqbal $M N$, Qayyum $M$. Detection of multiple anthelmintic resistance of Haemonchus contortus and Teladorsagia circumcincta in sheep and goats of northern Punjab, Pakistan. Kafkas Univ Vet Fak Derg 2015; 21:389-395.

54. Khan MN, Sajid MS, Rizwan HM, Qudoos A, Abbas RZ, Riaz M, et al. Comparative efficacy of six anthelmintic treatments against natural infection of Fasciola species in sheep. Pak Vet J 2017; 37:65-68.

55. Masood S, Abbas RZ, Iqbal Z, Mansoor MK, Sindhu ZUD, Zia MA, et al. Role of natural antioxidants for the control of coccidiosis in poultry. Pak Vet J 2013; 33:401-407.

56. Kaplan RM. Drug resistance in nematodes of veterinary importance: A status report. Trends Parasitol 2004; 20:477-481.

57. Nicholas FW. Veterinary Genetics. Oxford University Press, Oxford, UK; 1987.

58. Saddiqi HA, Iqbal Z, Khan MN, Sarwar M, Muhammad G, Yasseen M, et al. Evaluation of three Pakistani sheep breeds for their natural resistance to artificial infection of Haemonchus contortus. Vet Parasitol 2010; 168:141-145.

59. Stear MJ, Doligalska M, Donskow-Schmelter K. Alternatives to anthelmintics for the control of nematodes in livestock. Parasitol 2007; 134:139-151.

60. Afaq M. Parasitic control practices and anthelmintic resistance against gastrointestinal nematodes of sheep. Ph.D. Thesis, Dept Vet Parasitol Univ Agriculture, Faisalabad, Pakistan. 2003.

61. Hamad KK. Combined strategies to control antinematicidal resistant gastrointestinal nematodes in small ruminants on organized farms in Pakistan. Pak J Agri Sci 2014; 51:241-249.

62. Waller PJ, Bernes G, Rudby-Martin L, Ljungstrom BL, Rydzik A. Evaluation of copper supplementation to control Haemonchus contortus infections of sheep in Sweden. Acta Vet Scand 2004; 45:149-160.

63. Waller PJ, Thamsborg SM. Nematode control in 'green' ruminant production systems. Trends Parasitol 2005; 20:493-497.

64. Jabbar A, Iqbal Z, Kerboeuf D, Muhammad G, Khan MN, Afaq M. Anthelmintic resistance: The state of play revisited. Life Sci 2006; 79:2413-2431.

65. Satyavati GV, Raina MK, Sharma M. Medicinal Plants of India. New Delhi, India. Indian Counc Med Res 1976; 1:201-206.

66. Rashid MD, Tanzin R, Ghosh KC, Jahan R, Khatun A, Rahmatullah M. An ethnoveterinary survey of medicinal plants used to treat cattle diseases in Birishiri area, Netrakona district, Bangladesh, Advan Nat Appl Sci 2010; 4:10-13.

67. Zaman MA, Iqbal Z, Abbas RZ, Khan MN, Muhammad $\mathrm{G}$, Younus $\mathrm{M}$, et al. In vitro and in vivo acaricidal activity of a herbal extract. Vet Parasitol 2012; 186:431-436.

68. Khan ZI, Omar S, Ahmad K, Bashir H, Sohail M, Ayub $\mathrm{M}$, et al. Assessment of macro minerals and their distribution and concentration in soil-plant-animal systems in Shor Kot, Pakistan. J Dairy Vet Anim Res 2017a; 5:131.

69. Badar N, Iqbal Z, Sajid MS, Rizwan HM, Jabbar A, Babar W, et al. A document on the ethnoveterinary practices in district Jhang, Pakistan. J Anim Plant Sci 2017; 27:398-406.

70. Badar SN, Iqbal Z, Sajid MS, Rizwan HM, Shareef M, Malik MA et al. Comparative anthelmintic efficacy of 
Arundo donax, Areca catechu, and Ferula assafoetida against Haemonchus contortus. Revista Brasileira de Parasitologia Veterinária 2021; 30(2):e001221.

71. Acharya D, Anshu S. Indigenous herbal medicines: Tribal formulations and traditional herbal practices. Aavishkar Publishers, Jaipur, India 2008; 962.

72. Tabuti JR, Dhillion SS, Lye KA. Ethnoveterinary medicines for cattle (Bos indicus) in Bulamogi County, Uganda: plant species and mode of use. J Ethnopharmacol 2003; 88:279-286.

73. Fabricant DS, Farnworth NR. The value of plants used in traditional medicine for drug discovery. Environ Health Perspect 2001; 1:69-75.

74. Shrivastava S, Jain AK, Tomar RS. Ethnoveterinary practices: a review on phytotherapeutical approaches in treatment of animals. World J Pharma Med Res 2017; 3:96-100.

75. Elvin-Lewis M. Should we be concerned about herbal remedies. J Ethnopharmacol 2001; 75:141-164.

76. George P. Concerns regarding the safety and toxicity of medicinal plants: An overview. J Appl Pharm Sci 2011; 1(6):40-44.

77. Abbas RZ, Zaman MA, Sindhu ZD, Sharif M, Rafique A, Saeed Z, et al. Anthelmintic effects and toxicity analysis of herbal dewormer against the infection of Haemonchus contortus and Fasciola hepatica in goat. Pak Vet J 2020; 40(4):455-460

78. Knox MR, Torres-Acosta JFJ, Aguilar-Caballero AJ. Exploiting the effect of dietary supplementation of small ruminants on resilience and resistance against gastrointestinal nematodes. Vet Parasitol 2006; 139:385-393.

79. Khan RN, Usmani RH. Characteristics of rural subsistence smallholder livestock production system in mountainous areas of NWFP, Pakistan. Pak Vet J 2005; 25:115-120.

80. Waller PJ, Barnes G, Thamsborg SM, Sukura A, Richter $\mathrm{SH}$, Ingebrigtsens $\mathrm{K}$ et al. Plants have deworming agents of livestock in the Nordic countries: Historical prospective, popular beliefs and prospectus for the future. Acta Vet Scandinavia 2001; 42:31-44.

81. Goraya K, Iqbal Z, Sajid MS, Muhammad G, Ain QU, Saleem M. Diversity of flora used for cure of equine diseases in selected peri urban areas of Punjab, Pakistan. J Ethnobiol Ethnomed 2013; 9:70.

82. Panda SS, Dhal NK. Plants used in ethno-veterinary medicine by native people of Nawarangpur district, Odisha, India. World J Pharm Pharma Sci 2014; 3:787798.

83. Molan AL, Waghorn GC, Min BR, McNabb WC. The effect of condensed tannins from seven herbages on Trichostrongylus colubriformis larval migration in vitro. Folia Parasitol 2000; 47:39-44.

84. Iqbal Z, Mufti KA, Khan MN. Anthelmintic effects of condensed tannins. Int J Agri Biol 2002; 4:438-440.

85. Pavan R, Jain S, Shraddha, Kumar A. Properties and therapeutic application of bromelain: A review. Biotechnol Res Int 2012; 2012:1-6.

86. Stepek G, Buttle DJ, Duce IR, Lowe A, Behnke JM. Assessment of the anthelmintic effect of natural plant cysteine proteinases against the gastrointestinal nematode, Heligmosomoides polygyrus in vitro. Parasitol 2005; 130:203-211.

87. Buttle DJ, Behnke JM, Bartley Y, Elsheikha HM, Bartley DJ, Garnett MC, et al. Oral dosing with Papaya latex is an effective anthelmintic treatment for sheep infected with Haemonchus contortus. Parasit Vectors 2011; 4:36.

88. Asif M, Azeem S, Asif S, Nazir S. Prevalence of gastrointestinal parasites of sheep and goats in and around Rawalpindi and Islamabad, Pakistan. J Vet Anim Sci 2008; 1:14-17.

89. Al-Shaibani IRM, Phulan MS, Arijo A, Qureshi TA. Epidemiology of ovine gastrointestinal nematodes in Hyderabad district, Pakistan. Pak Vet J 2008; 28:125130.

90. Khan MN, Sajid MS, Khan MK, Iqbal Z, Hussain A. Gastrointestinal helminthiasis: Prevalence and associated determinants in domestic ruminants of district Toba Tek Singh, Punjab, Pakistan. Parasitol Res 2010; 107:787-794.

91. Mehmood K, Ijaz IM, Durrani AZ, Khan MA, Sabir AJ, Saleem MH. Infection rate and therapeutic trials on various gastrointestinal parasites in sheep and goats in and around Lahore, Pakistan. Pak J Zool 2013; 45:489494.

92. Kakar H, Lateef M, Maqbool A, Jabbar MA, Abbas F, Jan S, et al. Prevalence and intensity of ovine gastrointestinal nematodes in Balochistan, Pakistan. Pak J Zool 2013; 45:1669-1677.

93. Shah H, Zahid M, Khan MA, Jan A, Haseeb A, Ullah R. Detection of gastrointestinal helminthiasis through coprological examination in small ruminants in and around Agriculture University Peshawar, Pakistan. World J Zool 2015; 10:211-215.

94. Rizwan HM, Sajid MS, Iqbal Z, Saqib M. Point prevalence of gastrointestinal parasites of domestic sheep (Ovis aries) in district Sialkot, Punjab, Pakistan. J Anim Plant Sci 2017; 27(3):803-808.

95. Umur S, Yukari BA. An abattoir survey of gastrointestinal nematodes in sheep in the Burder region, Turkey. Turk J Vet Anim Sci 2005; 29:1195-1201.

96. Odoi A, Gathuma JM, Gachuiri CK, Omore A. Risk factors of gastrointestinal nematode parasite infections in small ruminants kept in smallholder mixed farms in Kenya. BMC Vet Res 2007; 3:6.

97. Ibrahim MM, Ghamdi MMA, Gahmdi MSA. Helminths community of veterinary importance of livestock in relation to some ecological and biological factors. Turkey J Parasitol 2008; 32:42-47.

98. Sultan K, Desoukey AY, Elsiefy MA, Elbahy NM. An abattoir study on the prevalence of some gastrointestinal helminths of sheep in Gharbia Governorate, Egypt. Global Vet 2010; 5:84-87.

99. Dagnachew S, Amamute A, Temegen W. Epidemiology of gastrointestinal helminthiasis of small ruminants in selected sites of north Gondar zone, northwest Ethiopia. Ethiopian Vet J 2011; 15:57-68.

100. Idris A, Moors E, Sohnrey B, Gauly M. Gastrointestinal nematode infections in German sheep. Parasitol Res 2012; 110:1453-1459. 
101.Ntonifor HN, Shei SJ, Ndaleh NW, Mbunkur GN. Epidemiological studies of gastrointestinal parasitic infections in ruminants in Jakiri, Bui Division, northwest region of Cameroon. J Vet Med Anim Hlth 2013; 5:344-352.

102.Kandasamy G, Rajapakse RPVJ, Rajakaruna RS. Gastrointestinal and blood parasites of a free grazing flock of sheep in Kaithady farm in the Jaffna District. J Natn Sci 2013; 41:195-201.

103.Koinari M, Kar S, Ryan U, Lymbery AJ. Infection levels of gastrointestinal parasites in sheep and goats in Papua New Guinea. J Helminthol 2013; 87:409-15.

104.Bhat AS, Reshi AA, Mir RM, Husain I, Sheikh BA, Khan HM. Assessment of prevalence of parasitic infections in sheep reared in Kashmir valley, India. J Anim Prod Adv 2014; 4:416-421.

105.Minnat TR. Detection of gastrointestinal parasite infection of sheep and goats in Diyala Province-Iraq. AL-Qadisiya J Vet Med Sci 2014; 13:118-123.

106.Jegede OC, Adejoh AA, Obeta SS, Olayemi OD. Gastrointestinal parasites of sheep and goats in Gwagwalada area council, federal capital territory, Abuja, Nigeria with a special reference to sex, breed and age. Alexandria J Vet Sci 2015; 46:170-176.
107.Acocks JPH. Veld types of South Africa. In: Leistner AO, Uestaan-Deur, Momberg BA. Memoirs of Botanical Survey of South Africa. Botanical Research Institute Pretoria, Department of Agriculture and Water Supply 1975; p. 57.

108.Atal CK. Potential Newer Medicinal Plants: Report of the Seminar on Medicinal Plants, Phytomedical and Bulk Drugs. Mumbai, Chemexcil 1983; 34-36.

109. Hutchings A. Observations on plant usage in Xhosa and Zulu medicine. Bothalia 1989; 19:225-235.

110.Akhtar MS, Iqbal Z, Khan MN, Lateef M. Anthelmintic activity of medicinal plants with particular reference to their use in animals in the Indo-Pakistan subcontinent. Small Rumin Res 2000; 38:99-107.

111.Coetzee E. The magic of muti plants. Farmer's Weekly $2000 ; 14: 26-29$.

112.Axford RFE, Bishop SR, Nicholas FW, Owen, JB. Breeding for Disease Resistance in Farm Animals, second edition. Wallingford, CABI Publishing 2000; 129-135.

113.Sanhokwe M. Mupangwa J, Masika PJ, Maphosa V, Muchenje V. Medicinal plants used to control internal and external parasites in goats, Onderst J Vet Res 2016; 83(1):1-7. 